
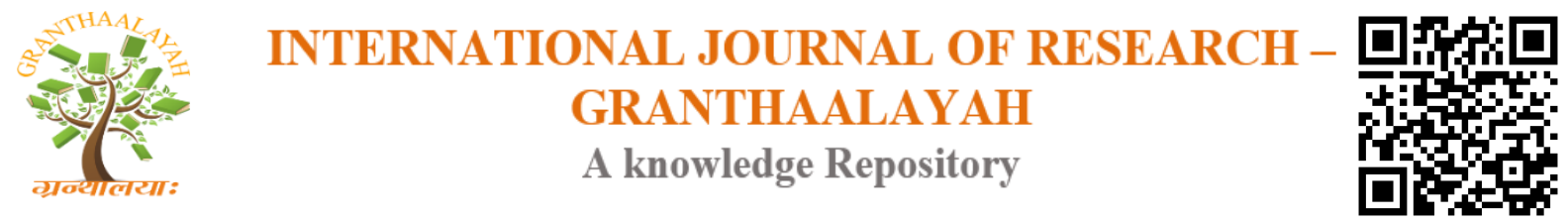

Management

\title{
A STUDY OF CERTIFIED FINANCIAL AUDITOR: THE EFFECT OF CAREER DEVELOPMENT AND CERTIFICATION ON PERFORMANCE MEDIATED BY WORK MOTIVATION
}

\author{
Zaid Kamal ${ }^{1}$, Erna Handayani ${ }^{2}$, Siswoyo Haryono *3 \\ ${ }^{1}$ Faculty of Economics, Universitas Persada Indonesia, Jakarta, Indonesia \\ 2, 3 Doctoral in Management, Postgraduate School, Universitas Muhammadiyah Yogyakarta
}

\begin{abstract}
This research aimed to obtain an accurate picture of facts related to the object of research, such as a description of the characteristics of career development variables, auditor certification, work motivation, and auditor performance. The hypothesis testing with SEM (Structural Equation Modeling) based on data obtained in the field, namely testing the effect of career development and certification on performance mediated by motivation. This research was to test; 1) The effect of either partially or jointly career development and auditor certification on work motivation; 2) The effect of either partially or jointly career development, auditor certification, and work motivation on auditor performance.

This study amounted to 240, an auditor who was in the Inspectorate units of the South Sumatra working area. The finding showed there is a positive and significant influence of career development and auditor certification on the work motivation of auditors in the South Sumatra Inspectorate Office. e.

The motivation, career development, and auditor certification significantly affect the auditor performance in the South Sumatra Inspectorate Office. There is a positive and significant influence on career development, auditor certification, and work motivation together on the performance of auditors in the South Sumatra Inspectorate Office.
\end{abstract}

Keywords: Career Development; Auditor Certification; Work Motivation; Employee Performance.

Cite This Article: Zaid Kamal, Erna Handayani, and Siswoyo Haryono. (2020). "A STUDY OF CERTIFIED FINANCIAL AUDITOR: THE EFFECT OF CAREER DEVELOPMENT AND CERTIFICATION ON PERFORMANCE MEDIATED BY WORK MOTIVATION." International Journal of Research - Granthaalayah, 8(4), 23-31. https://doi.org/10.29121/granthaalayah.v8.i4.2020.4.

\section{Introduction}

The quality of auditor performance in Inspectorate work units in the South Sumatra Province is still not optimal. Based on the pre-survey results, the researchers found that the quality of work 
completion and timeliness of completion of one job was still lacking. The head of Financial and Development Supervisory Agency Decree Number: Kep-06.04.00-373 / K / 1997 dated June 6, 1997, regarding the technical guidelines for certification implementation and auditor functional education and Training for the government functional supervisory apparatus, the South Sumatra Province Inspector has carried out procedures certification that must be carried out by a prospective auditor or by the Auditor to obtain an auditor's certificate. The Auditor's certification as one of the auditors' self-development tools as part of human resource development (BPKP, 1997)

Mubarok and Putra (2018) define employee development, or competencies must be with training development and motivation to the employees. Auditors' self-development in a government agency will undoubtedly increase their activities according to their main tasks and functions. Employee development in a narrow view through the method of education and training (training). Because of that, usually, a government or bureaucratic organization conducts Training and Training related to day-to-day work operations in order to improve performance or public services (Joseph, 2017) To achieve the level of professionalism of the supervisory apparatus, one of the means is through education and training auditor certification. The purpose of the Training, as mentioned in Indonesian government regulation No. 101 of 2000, among others, is increasing knowledge, expertise, skills, and attitudes. The functional auditor certification course aimed to increase the knowledge, skills, and change the behavior of auditors at a certain level of competence according to their role. (BPKP, 2007).

H.R. managers should learn about the employees' values, needs, and satisfaction levels to improve work performance (Haryono et al., 2020). The success of the South Sumatra Province Inspector is also primarily determined by the level of work motivation of its employees. Employees who have high work motivation will work optimally. Al-Khalifa and Peterson (2004) argued that: "Employee performance will increase if employees felt satisfied in their work and motivated to do work." Based on the statement above, it is clear that the low performance of employees is allegedly due to low employee motivation. While Kenneth (2010) states that employee performance determines the career development of employees at work. If described from some of the theories above, it can be seen in Figure 1.1 below:

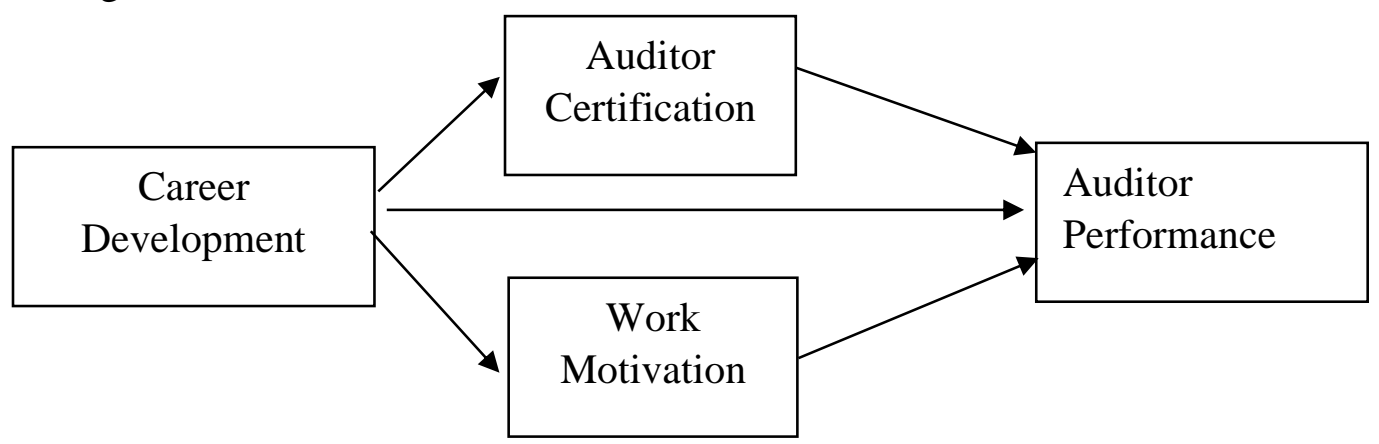

Figure 1.1: Relationship Between Career Development, Auditor Certification, Work Motivation and Auditor Performance.

Sources: (Al-Khalifa and Peterson, 2004)

Based on Figure 1.1. Above, it turns out that the low performance of the Inspectorate of the work area of the South Sumatra Province is allegedly due to the suboptimal implementation of career development programs, and auditor certification, this has an impact on the work motivation of 
auditors, to do work that could have implications for auditor job dissatisfaction. Facts on the ground indicate that work motivation in the South Sumatra Inspectorate Office is still low. The quality of work is not right; employees work without high moral and just carry out obligations; this has an impact on the poor performance of the Auditor.

\section{Literature Review and Hypothesis Development}

\subsection{The Effect of Career Development and Auditor Certification on Work Motivation}

According to Dessler (2013), a career is a series of positions related to work, whether paid or not, which can help someone to grow, be skilled, succeed in fulfilling work. According to Jeffrey (2015), careers are; "The sequence of a person's work-related activities and behaviors and associated attitudes, values, and aspirations throughout one's life." According to (Robbins 2018), a career is a practical guide that advances systematically through specific channels. Career development consists of personal improvement done by someone in achieving his career plan (Rivai, 2009). Development is more focused on the development of a person (Nedler, 1984) (Rowley et al., 2012). Development is the second operational function of personnel management. An employee development program must first be the priority (Al Hashmi et al., 2019).

According to Dessler (2013), career planning includes individual career planning and organizational career planning. The definition of individual career planning is "the process that each employee personally plans career goals," while the organization's career planning is "the process of employee management career plans." Meanwhile, according to Noe at al. (2015), "Career planning is an ongoing process whereby an individual set of career goals and identifies the means to achieve them." According to Berman et al. (2019), "career planning is the process through which individual employees identify and implement steps to attain career goals." According to Dean and Joseph (2015), career planning is a process of employees to be aware of self, opportunities, constraints, choices, and consequences. Other benefits of career planning are identifying career-related goals, programming of work, education, and related developmental experiences. The ultimate goal of career planning is to provide the direction, timing, and sequence of steps to attain specific career goals".

Gibson and Ivancevich (2012) argued that career development is "a formal approach is to ensure that people with the proper qualifications and experience are available when needed." Meanwhile, according to (Noe A. Raymond, Hollenbec R. John, Gerhart Bary, 2015), "career development encompasses career management and career planning. Career planning is the process through which individual employees identify and implement steps to attain career goals. Career management is the process which organizations select, assess, assign, and develop employees. caree management is to provide a pool of qualified people to meet future needs ". According to Dessler (2013), "Career development is a deliberate process through which a person becomes aware of the attributes associated with personal careers and a series of steps throughout life that contribute to the fulfillment of his career." Career development is the process of identifying employee career potential and material and applying appropriate ways to develop that potential (Rivai, 2009). Career development prepares employees to stay in line with organizational change and growth. Development activities have the potential to align employees with their company strategies (Khan et al., 2014). The decree of the Minister of the Interior Number 47 of 2010, 
regarding the instructions for the functional position of the supervisor of regional government affairs, that career guidance includes; (1) first appointment (2) appointment of transfer (3) promotion/rank (4) temporary release (5) reappointment (6) termination of position.

The term audit comes from the word "Audere," which means to hear, taken from the practice of the Kings in ancient times, who conduct an examination of the finances of his country by listening to reports read by the Treasurer / Minister of Finance. Eventually, the word Audere, which initially meant to hear changed into an audit and interpreted as an examination (STAN, 2007). According to PER / 220 / M.PAN / 7/2008, Auditors are positions that have the scope, duties, responsibilities, and authority to carry out the internal supervision of government agencies. Auditors are civil servants with rights and obligations granted in full by the authorized official. The main task of the Auditor is to carry out planning, organizing, technical implementation, control, and evaluation activities. Auditor certification is evidence of recognition of the ability of auditors. Recognition is also essential in order to increase motivation and satisfaction. (Asaari et al., 2019).

Mohamud et al. (2017) state that works motivation is a term used in organizational behavior to describe the strengths in an individual, which explains the level, direction, and perseverance of effort expended at work. Meanwhile, Mangkunegara (2007) states as follows: "Work motivation is conditions which influence the arousal, direction, and maintenance of relevant behaviors in work settings." Several theories discuss work motivation, in general, content theories, and process theories (Robbins, 2018). In this research, the theoretical approach taken or discussed is about content theories. This theory tries to explain the factors that exist in individuals and the environment. Specific needs that motivate individual work behavior (Luthan, 2002) The implications for this theory are: Need Hierarchy Theory from Maslow, ERG Theory from Alfader, and Two Factor Theory from Herzberg.

Some research related to career development found that salespeople with the fairness of compensation and satisfying opportunities to advance in career paths have a relationship with work performance (Sutanto, 2003). Leadership, Career path, and Awards affect work satisfaction (Djestawana, 2012). Organizational culture, career development, and work motivation jointly influence performance (Suwarto, 2015). Bahri (2017) found that career development had a significant positive effect on work motivation and employee performance, where Career development variables provide greater determination than motivation variables in influencing performance variables.

Research related to Auditor Certification has been conducted by Tugiman (2000), which proves that the role of auditors significantly affects internal control and organization performance. Gunasti (2009) proves that experience and competence have a significant effect on auditor professionalism. (Tietjen \& Myers, 1998) the journal Management Decision states, "By understanding these theories, managers can focus on strategies of creating job satisfaction. A brief examination of Kenneth Blanchard and Paul Hersey's theory on leadership within management and how this art is changing through time ". Research by (Al-Khalifa and Peterson, 2004) (Osteraker, 1999) and (Milne 2007) concluded that motivation significantly affects employee satisfaction. Motivation significantly affects employee performance if environmental factors support a better direction. The amount of employee incentives also has a positive influence on work motivation and will have an impact on the optimization of organizational work. Work motivation and organizational culture 
together have a positive and significant effect on employee performance, but in this study, organizational culture factors are more dominant. Work motivation has a significant effect on organizational effectiveness.

Based on some literature reviews and previous researches, it is clear that career development and auditor certification have some positive impacts on the organization, especially in increasing work motivation. Finally, if the work motivation increase, the performance will also increase. The hypothesis is:

$\mathrm{H}_{1}$ : Career development significantly affects auditor work motivation in South Sumatra Inspectorate Office.

$\mathrm{H}_{2}$ : Auditor certification significantly affects auditor work motivation in South Sumatra Inspectorate Office.

\subsection{The Effect of Career Development, Auditor Certification, and Motivation on Performance.}

Related to Nicole's employee performance research in 2008, the findings revealed that the implementation of HRM significantly affects employee wellness. The fast result in the study was that support and development of trust promoted employee wellness. In general, the findings support human resource practitioners, management, policymakers, and business practice. Topper (2007) found that employee supervision is no more effective than growing employee work motivation itself.

Employee performance will be optimal if a good relationship between employees, employee welfare, and promotions is by employee competencies. High motivation and commitment to work, as well as excellent organizational behavior, will have an impact on improving employee performance. Factors of a conducive work environment will positively influence performance, which in turn will increase employee work productivity. There needs to be a working system that is suitable for the organization, secure communication between fellow employees and employees with the leadership, and the implementation of employee training as a means to improve employee competence.

$\mathrm{H}_{3}$ : Career development significantly affects auditor performance in South Sumatra Inspectorate Office.

$\mathrm{H}_{4}$ : Auditor certification significantly affects auditor performance in South Sumatra Inspectorate Office.

$\mathrm{H}_{5}$ : Work motivation significantly affects auditor performance in South Sumatra Inspectorate Office.

\section{Materials and Methods}

The form of research used is descriptive and verification. Descriptive research was to obtain an accurate picture of facts related to the object of research, such as a description of the characteristics of career development variables, auditor certification, work motivation, and auditor performance. 
While verification research is to produce scientific information through hypothesis testing with SEM (structural Equation Modeling) based on data obtained, SEM method is to analyze research that has several independent (exogenous), dependent (endogenous), moderating, and intervening variables partially and simultaneously (Haryono, 2017). The unit of analysis in this study are individuals, namely auditors in the South Sumatra Inspectorate Office within the working area of the Province of South Sumatra.

The population in this study were all auditors in the South Sumatra Inspectorate Office of the South Sumatra working area totaling 434 auditors. The sampling technique in this study was probability sampling, with a total sample of 240 auditors. The subject matter examined is work motivation and performance as endogenous variables, then career development and auditor certification as exogenous independent variables. The score of each variable is from each statement developed from several component indicators. From each statement, five answer choices, namely: (S.A.) Strongly Agree, (A) Agree, (N) Neutral, (DA) Disagree, (S.D.) Strongly Disagree. Scores move from 5 for those who answered S.A.. 4 for those who answered A. 3 for those who answered N. 2 for those who answered D.A.. 1 for those who answered S.D. Before the inferential analysis, there was validity and reliability test of the instruments - the analysis of the data based on valid and reliable instruments.

\section{Results and Discussions}

Table 1: Path Coefficient, Critical Ratio (C.R.) and Probability Value

\begin{tabular}{|l|l|l|c|c|c|c|}
\hline \multicolumn{2}{|l|}{} & Estimate & SE & CR & P \\
\hline Work motivatoion & $<---$ & Career development & .082 & .034 & 2.398 & .016 \\
\hline Work motivatoion & $<---$ & Auditor sertification & .182 & .037 & 4.949 & $* * *$ \\
\hline Auditor performance & $<---$ & Career development & .134 & .053 & 2.505 & .012 \\
\hline Auditor performance $<---$ & Work motivatoion & .351 & .173 & 2.028 & .043 \\
\hline Auditor performance $<---$ & Auditor sertification & .162 & .060 & 2.708 & .007 \\
\hline
\end{tabular}

1) Career development significantly affects auditor work motivation in South Sumatra Inspectorate Office. The conclusion is on the results of the t-Value or C.R. of 2.398>1.967 or a P-value of $0.016<0.05$, and the regression coefficient value obtained was positive at 0.213 . Even without making efforts to improve other variables, the work motivation of auditors in the South Sumatra Inspectorate Office can be through proper career development.

2) Auditor certification significantly affects auditor work motivation in South Sumatra Inspectorate Office. The conclusion is on the results of the t value or C.R. of 4.949>1.967, or there is a $* * * *$ mark on the $\mathrm{P}$-value, and the regression coefficient value obtained is positive at 0.470 . There will be an increase in the work motivation of auditors in the units of the South Sumatra Inspectorate Office if accompanied by the certification of auditors.

3) 3. Career development significantly affects auditor performance in South Sumatra Inspectorate Office. The conclusion is on the results of the t value or C.R. of 2.028>1.967 or a P-value of $0.043<0.05$, and the regression coefficient value obtained was positive at 0.245 . There will be an increase in the performance of auditors in the units of the South Sumatra Inspectorate Office if it is optimized, motivating the auditors in the South Sumatra Inspectorate Office. 
4) Auditor certification significantly affects auditor performance in South Sumatra Inspectorate Office. The conclusion is on the results of the t value or C.R. of 2.505>1.967 or a P-value of $0.012<0.05$ and a positive regression coefficient obtained of 0.241 . There will be an increase in the performance of auditors in the units of the South Sumatra Inspectorate Office if coupled with the excellent career development of auditors in the South Sumatra Inspectorate Office.

5) Work motivation significantly affects auditor performance in South Sumatra Inspectorate Office. The conclusion is on the results of $t$ value or C.R. of 2.708>1.967 or P-value of $0.007<0.05$, and the regression coefficient value obtained was positive at 0.293 . There will be an increase in the performance of auditors in the units of the South Sumatra Inspectorate Office if accompanied by the implementation of a proper auditor certification training for auditors in the South Sumatra Inspectorate Office.

From the analysis of the direct, indirect, and total effects, career development and auditor certification on work motivation show that auditor certification has the highest total effect $(0.470)$ than on the total effects of career development (0.213). The indirect effect of career development on auditor performance is 0.052 . The direct effect of career development is greater than the direct effect of career development on auditor performance that is only 0.045 . The indirect effect of auditor certification on auditor performance is 0.115 . It is greater than the direct effect of auditor certification on auditor performance that is 0.085 . It means that work motivation is as a mediator in this model. The total effect of career development, auditor certification, and motivation on the performance show that auditor certification has the highest total effect (0.408) on performance through motivation - the total effect of career development (0.294) and work motivation (0.245). Increasing auditor performance is the most effective through auditor certification mediated by work performance.

\section{Conclusions and Recommendations}

The conclusions and recommendations are:

1) Career development significantly affects work motivation in South Sumatra Inspectorate Office. The recommendation to increase the work motivation of auditors in the South Sumatra Inspectorate Office, the management should carry out the career development of the auditors proportionally.

2) Auditor certification significantly affects work motivation in South Sumatra Inspectorate Office. The recommendation to increase the work motivation of auditors in the South Sumatra Inspectorate Office, the management should carry out an education and training program for the certification of auditors or prospective auditors optimally.

3) Career development significantly affects auditor performance in South Sumatra Inspectorate Office. The recommendation to improve auditor performance in the South Sumatra Inspectorate Office can be by increasing the motivation of auditors.

4) Auditor certification significantly affects auditor performance in South Sumatra Inspectorate Office. The recommendation to improve the performance of auditors in the South Sumatra Inspectorate Office by increasing auditor career development.

5) Work motivation significantly affects auditor performance in South Sumatra Inspectorate Office. The recommendation of improving the performance of auditors in the South Sumatra Inspectorate Office can be by carrying out education and training programs for auditors or prospective auditor certification. 
6) Increasing work motivation requires proportional career development because it significantly affects motivation. Career development efforts can be through the following matters; 1). Giving or career development must be following interests and talents, 2). The ongoing communication between management and auditors regarding career planning, 3). Have clear goals in career planning; 4)-improvement of employee recruitment systems.

7) Increasing work motivation required an auditor who has auditor certification because auditor certification significantly affects motivation. Efforts to improve auditor certification can be through planning and implementation and taking into account the following matters; 1). The auditors follow the Training to improve abilities and skills, 2). Management gives reasonable control to auditors who follow Training and Training, 3) training Materials following the given task field.

8) Increasing employee performance requires high employee motivation because motivation significantly effects on employee performance. Efforts to improve performance can be through motivational management practices that seek to provide; 1). Achievement needs; a). The efforts to improve achievement are through: b). Challenging work, 2). Affiliations (Relatedness) include; a). Collaborate in carrying out tasks, b). Obey the rules, and 3). Power Needs; a). Self-esteem, b). Respect for self.

9) To improve the performance of auditors through 1). Work quality; a). The draft work plan, b). Preparation of work programs, 2). Work Quantity; a). Direct coaching, b). The concept of making essential letters, and 3). Reliability: a). Audit transparency, b). Responsibility, c). Help each other.

The limitation of this study is the number and extent of the scope of the objects used as respondents. The research will be more applicable if applied in all sectors and with a higher number of respondents. To contribute ideas for further research, can explain the pattern of relationships and the influence of strategy in terms of employee career generation decisions, increase employee competency and tackle other factors related to increased work motivation and employee performance.

\section{References}

[1] Abu Hassan Asaari, M. H., Mat Desa, N., \& Subramaniam, L. (2019). Influence of Salary, Promotion, and Recognition toward Work Motivation among Government Trade Agency Employees. International Journal of Business and Management, 14(4), 48. https://doi.org/10.5539/ijbm.v14n4p48.

[2] Al-Khalifa and Peterson. (2004). On the Relationship Between Initial Motivation and Satisfaction and Performance in Joint Ventures. Europan Journal of Marketing.

[3] Al Hashmi, W. S. G., Cooling, R., Al Hashmi, W. S. G., \& Cooling, R. (2019). Organizational behavior and human resource management. The 10 Step MBA for Safety and Health Practitioners. https://doi.org/10.4324/9781315743011-5.

[4] Bahri, S., and Y. C. N. (2017). Pengaruh Pengembangan Karir dan Motivasi Kerja terhadap Kepuasan Kerja Karyawan. Jimb, 18(1), 7. http://jurnal.umsu.ac.id/index.php/mbisnis.

[5] Berman, E.M., Bowman, J.S., Est, J.P., \& Van Mart, M. R. (2019). Human Resource Management in Public Service: Paradoxes, Processes, and Problems. C.Q. Press.

[6] BPKP. (1997). Sertifikasi Auditor.

[7] BPKP. (2007). Akuntabilitas Instansi Pemerintah.

[8] Dean, M.R.W \& Joseph, M. J. (2015). Human Resource Management (14 to edit). Mc Graw-Hill education. 
[9] Dessler. Garry (2013). Human Resources Management (Fifteenth). Pearson.

[10] Djestawana, I. G. G. (2012). Pengaruh Pengembangan Organisasi, Kepemimpinan, Jenjang Karir terhadap Kepuasan Kerja dan Kinerja Pegawai Puskesmas. Kosmas: National Public Health Journal, 6(6), 261. https://doi.org/10.21109/kesmas.v616.79.

[11] Gibson L. James, Ivancevich M. John, D. H. J. (2012). Organizations: Behavior, Structure, Processes. (Fourteenth). Mc Graw-Hill Education.

[12] Haryono, S. (2017). Metode SEM Untuk Penelitian Dengan AMOS Lisrel PLS. Lucia Metro Media.

[13] Haryono, S., Supardi, S., \& Udin, U. (2020). The effect of Training and job promotion on work motivation and its implications on job performance: Evidence from Indonesia. 10, 2107-2112. https://doi.org/10.5267/j.msl.2020.1.019.

[14] Jeffrey, M. A. (2015). Strategic Human Resources Management (4th edition). Cengage Learning.

[15] Joseph, C. E. (2017). Organizational Behavior: Integrating Individuals, Groups, and Organization (Fifth edition).

[16] Kenneth, R. (2010). The beat and rhythm of competency development over two years. Journal of Management Development, Unit 07, 1-5.

[17] Khan, N., Ahmad, N., Iqbal, N., \& Haider, N. (2014). Relationship of Training and Education with Employee Performance in Financial Institutions. International Letters of Social and Humanistic Sciences, 41(2012), 150-156. https://doi.org/10.18052/www.scipress.com/ilshs.41.150.

[18] Luthan, F. (2002). Organizational Behavior (Ninth Edi). Mc Graw-Hil education.

[19] Mangkunegara, A. P. A. (2007). Evaluasi Kinerja Sumber Daya Manusia (R. Aditama(ed.)).

[20] Milne, P. (2007). Motivation, incentives, and organizational culture. Journal of Knowledge Management, 11(6), 28-38. https://doi.org/10.1108/13673270710832145.

[21] Mohamud, S. A., Ibrahim, A. A., \& Hussein, J. M. (2017). The effect of motivation on employee performance: A case study in Hormuud company in Mogadishu Somalia. International Journal of Development Research, 7(11), 17001-17008. http://www.journalijdr.com.

[22] Mubarok, E. S., \& Putra, H. (2018). The Influence of Training, Competence, and Motivation on Employees Performance of Workers Social Security Agency in Banten Province, Indonesia. Journal of Economics and Sustainable Development Www.Iiste.Org ISSN, 9(4), 129-139. www.iiste.org.

[23] Noe A. Raymond, Hollenbec R. John, Gerhart Bary, W. M. P. (2015). Human Resources Management: Gaining a Competitive Advantage (10 edition). Mc Graw-Hill Education.

[24] Osteraker, M. C. (1999). Measuring motivation in a learning organization. Journal of Workplace Learning, 11(2), 73-77. https://doi.org/10.1108/13665629910260798.

[25] Rivai, V. (2009). Manajemen Sumber Daya Manusia untuk Perusahaan Dari Teori ke Praktek. PT Raja Grafindo.

[26] Robbins P. Stephen, J. A. T. (2018). Essentials of Organizational Behavior (Fourteenth). Pearson.

[27] Rowley et al. (2012). Manajemen Sumber Daya Manusia: The Key Concepts. Rajagrafindo Persada.

[28] Sutanto, E. M. (2003). Hubungan Antara Temperamen Karyawan, Pemberian Kompensasi, Dan Jenjang Karier Yang Tersedia Terhadap Prestasi Kerja Karyawan. Jurnal Manajemen Dan Wirausaha, 5(1), 42-55. https://doi.org/10.9744/jmk.5.1.pp.42-55.

[29] Suwarto, F. (2015). Pengaruh Budaya Organisasi Dan Pengembangan. Jurnal Manajemen, XIX(02), $170-189$.

[30] Tietjen, M. A., \& Myers, R. M. (1998). Motivation and job satisfaction. Management Decision, 36(4), 226-231. https://doi.org/10.1108/00251749810211027.

[31] Topper, E. F. (2007). Stress in the library workplace. New Library World, 108(11-12), 561-564. https://doi.org/10.1108/03074800710838290.

\footnotetext{
*Corresponding author.

E-mail address: profsis12@gmail.com
} 